\title{
Prevalence and antibiotic susceptibility of methicillin-resistant Staphylococcus aureus in ocular infections
}

\author{
Prevalência e suscetibilidade antibiótica de Staphylococcus aureus resistente à meticilina \\ em infecções oculares
}

Maria Eugenia Vola ${ }^{1}$, Aline Silveira Moriyama ${ }^{1}$, Renato Lisboa ${ }^{1}$, Maria Magdalena Vola², Flávio Eduardo Hiral ${ }^{1}$, Paulo José Martins Bispo ${ }^{1}$, ANA LUISA HÖFLING-LIMA ${ }^{1}$

\begin{abstract}
Purpose: To study the prevalence of methicillin-resistant Staphylococcus aureus among S. aureus ocular infections in a tertiary health center in Brazil and compare antibiotic susceptibility patterns between MRSA and methicillin-susceptible $S$. aureus isolates.

Methods: Electronic records from the ocular microbiology laboratory of the Universidade Federal de São Paulo were retrospectively reviewed. During a 10-year period (between January 2000 and December 2009) all conjunctivitis, keratitis, and endophthalmitis cases with a positive culture for $\mathrm{S}$. aureus were identified. Antibiotic susceptibility was determined using the Kirby-Bauer disk diffusion method.

Results: Five hundred sixty-six S. aureus isolates were identified; of those, 56 (9.9\%) were resistant to methicillin. Throughout the 10-year period, Staphylococcus aureus showed a significant increasing trend from $7.55 \%$ to $16.18 \%$ among overall S. aurues infections ( $p=0.001)$ and from $3.7 \%$ to $13.16 \%$ in conjunctivitis ( $p=0.001)$. Conversely, we did not observe the same trend among those with keratitis $(p=0.38)$. Staphylococcus aureus isolates showed higher resistance rates to tobramycin, gentamicin, ciprofloxacin, gatifloxacin, and moxifloxacin when compared with $S$. aureus isolates $(p<0.001)$. All cases were susceptible to vancomycin.

Conclusion: We observed an increasing trend in the overall prevalence of Staphylococcus aureus ocular infections and statistically significant higher resistance rates to commonly used antibiotics compared to Staphylococcus aureus. Our data supports the need for constant bacterial surveillance and should be taken into consideration before initiating empiric treatment of ocular infections.
\end{abstract}

Keywords: Conjunctivitis; Keratitis; Endophthalmitis; Methicillin-resistant Staphylococcus aureus; Fluoroquinolones

\section{RESUMO}

Objetivo: Estudaraprevalência do Staphylococcus aureus resistenteàmeticilina nas infecções oculares causadas por S. aureus em um centro de saúde terciário no Brasile comparar o perfil de suscetibilidade antimicrobiana entre as cepas de Staphylococcus aureus resistente à meticilina e $\mathrm{S}$. aureus susceptível à meticilina

Métodos: Foi realizada uma análise retrospectiva dos arquivos do laboratório de microbiologia ocular da Universidade Federal de São Paulo e selecionados todos os casos de conjuntivite, ceratite e endoftalmite com cultivo positivo para S. aureus, durante um período de 10 anos (entre janeiro de 2000 e dezembro de 2009). Foi avaliada a prevalência deStaphylococcus aureus resistenteà meticilina e comparado o perfil de susceptibilidade antimicrobiano dos Staphylococcus aureus resistente à meticilina eS. aureus susceptível à meticilina.

Resultados: Quinhentos e sessenta e seis isolados de S. aureus foram identificados. Desses, 56 (9,9\%) apresentaram resistência à meticilina. Durante o período de 10 anos estudado, Staphylococcus aureus resistente à meticilina mostrou uma tendência significante de aumento de 7,6\% para 16,2\% entre as infecções oculares causadas por $\mathrm{S}$. aureus em geral $(p=0,001)$ e de 3,7\% para 13,2\% nas conjuntivites ( $p=0,001)$. A mesma tendência não foi observada entre as amostras de ceratite $(p=0,38)$. Os isolados de Staphylococcus aureus resistente à meticilina mostraram maiores taxas de resistência à tobramicina, gentamicina, ciprofloxacino, gatifloxacinoe moxifloxacino em comparação com os isolados de $\mathrm{S}$. aureus susceptível à meticilina $(p<0,001)$. Todos os casos foram susceptíveis à vancomicina.

Conclusão: Foi observada uma tendência de aumento na prevalência do Staphylococcus aureus resistente à meticilina nas infecções oculares causadas por $\mathrm{S}$. aureus, bem como taxas deresistência significantemente maiores aos antibióticos comumente utilizados na prática oftalmológica. Nossos dados alertam para a necessidade de constante vigilância de resistência bacteriana a antimicrobianos e devem ser considerados na eleição do tratamento empírico das infecções oculares.

Descritores: Conjuntivites; Ceratites; Endoftalmites; Staphylococcus aureus resistente à meticilina; Fluoroquinolonas

\section{INTRODUCTION}

Staphylococcus aureus is a major human pathogen responsible for a wide variety of ocular diseases, including sight-threatening infections ${ }^{(1-4)}$. Since the first report of a new strain of S. aureus, the so-called methicillin-resistant Staphylococcus aureus (MRSA), its prevalence and morbidity has been increasing worldwide. Moreover, the antibiotic susceptibility is decreasing, introducing new challenges regarding its treatment and making constant antibiotic surveillance a priority.

The mechanism of resistance to semisynthetic penicillins, including oxacillin and methicillin, is based on structural changes of its target site. MRSA has also developed resistance to this compound as well as all $\beta$-lactam agents by acquiring the mecA gene, which is car- 
ried on a large mobile genetic element called staphylococcal cassette chromosome mec (SCCmec). The mecA gene encodes for an alternative penicillin-binding protein: PBP2a, that has low affinity for $\beta$-lactam and allows MRSA strains to survive in different concentrations of these antimicrobial agents ${ }^{(5)}$. As a consequence, the treatment of MRSA infections has been restricted to selected antibiotics, usually glycopeptides. Furthermore, due to the high capability to develop resistance, MRSA strains with reduced susceptibility to vancomycin have been isolated ${ }^{(6)}$.

It is known that MRSA prevalence and antimicrobial susceptibility patterns have substantial geographical variation ${ }^{(7)}$. In the United States, the results from the Antibiotic Resistance Monitoring in Ocular Microorganisms (ARMOR) study showed a prevalence of $39 \%$ of MRSA among all S. aureus ocular isolates and a considerable increase in the resistance rates to fluoroquinolones ${ }^{(8)}$. Other studies conducted in developing countries showed similar resistance patterns and even higher prevalence rates that ranged from 34\% to $53 \%{ }^{(9,10)}$. Although these previous studies are important to guide the treatment of ocular infections, their results may not reflect the current prevalence of MRSA in other geographic areas. Therefore, the study of the prevalence and susceptibility of MRSA in Latin America is of major importance in the management of ocular infections.

The purpose of our study was to evaluate the prevalence of MRSA among S. aureus ocular infections in a tertiary health center in Brazil and compare antibiotic susceptibility patterns between MRSA and methicillin-susceptible S. aureus (MSSA) isolates.

\section{METHODS}

This was a retrospective study conducted at the Universidade Federal de São Paulo (UNIFESP), from January 2000 to December 2009. The Ocular Microbiology Laboratory receives specimens from emergency services and outpatient clinics referred to the São Paulo Hospital, a tertiary health center in São Paulo, Brazil. For this study isolates were deidentified in order to protect patient identity. Then, we reviewed electronic records from the ocular microbiology laboratory and identified all conjunctivitis, keratitis, and endophthalmitis cases with a positive culture for $S$. aureus. If records showed more than one diagnosis, the primary pathology or the more severe diagnosis was chosen. Consecutive and non-duplicate $S$. aureus isolates were included in the final analysis. Cultures were obtained from conjunctival swabs, corneal scrapings, surgically removed stitches, aqueous humor, vitreous, and surgically removed intraocular lenses. The Universidade Federal de São Paulo Ethical Committee approved the protocol (protocol number: 72618) and methods described adhered to the tenets of the Declaration of Helsinki.
As a routine in our service, Staphylococcus species were identified by standard biochemical tests including catalase, coagulase, and DNase tests. Antibiotic susceptibility was determined using the Kirby-Bauer disk diffusion method. Results were interpreted according to the latest Clinical Laboratory Standards Institute (CLSI) guidelines available at the time of the antibiotic susceptibility testing ${ }^{(11)}$. For the purpose of this study, isolates were considered resistant to methicillin if resistance to either oxacillin or cefoxitin was identified.

Prevalence of MRSA among S. aureus isolates was calculated on an annual basis for each diagnostic category (conjunctivitis, keratitis, and endophthalmitis) and for the overall number of cases (sum of the total number of cases). We also recorded the susceptibility to tobramycin, gentamicin, ciprofloxacin, gatifloxacin, moxifloxacin, and vancomycin of each of the strains and compared their rates between MRSA and MSSA isolates. Proportions were tested with the Fisher exact test and a trend test was performed to investigate changes in prevalence rates yearly. All statistical analyses were performed with commercially available software (Stata version 10, StataCorp, College Station, TX). P-values less than 0.05 were considered statistically significant.

\section{RESULTS}

We included in our study 566 S. aureus isolates identified from January 2000 to December 2009. Fifty-six isolates (9.9\%) were resistant to methicillin. The median age of included subjects was 35.8 years (range from 6 days to 98 years). Patients with positive MRSA samples were significantly younger than patients with MSSA samples (median age of 27.9 vs. 36.7, respectively, $p=0.014$ ). No difference in sex was found between groups.

Table 1 shows the number of MRSA cases per year according to diagnostic category. Throughout the 10-year period, MRSA showed a significant increasing trend from 7.55 to $16.18 \%$ among overall $S$. aureus infections $(p=0.001)$ and from 3.7 to $13.16 \%$ in conjunctivitis $(p=0.001)$. Conversely, we did not observe the same trend among those with keratitis $(p=0.38)$. The small number of endophthalmitis did not allow us to make statistical inferences.

MRSA was more prevalent in endophthalmitis cases than in conjunctivitis (21.4 vs. $10.0 \%$, respectively, $\mathrm{p}<0.001)$ or keratitis cases $(21.4$ vs. $8.4 \%$, respectively, $p<0.001)$. Besides, MRSA was more prevalent in endophthalmitis cases than in the sum of conjunctivitis and keratitis cases (21.4 vs. 9.3\%, respectively, $p=0.036$ ).

Figure 1 illustrates the antibiotic susceptibility rates of MRSA and MSSA isolates. Fifty-six point four percent (56.4\%) of MRSA strains were susceptible to tobramycin, $70 \%$ to gentamicin, $62 \%$ to ciprofloxacin, $88.4 \%$ to gatifloxacin, and $85.1 \%$ to moxifloxacin. For MSSA

Table 1. Annual prevalence of methicillin-resistant S. aureus (MRSA) and total S. aureus (SA) ocular infections according to diagnostic category

\begin{tabular}{|c|c|c|c|c|c|c|c|c|}
\hline \multirow[b]{2}{*}{ Year } & \multicolumn{2}{|c|}{ Conjunctivitis } & \multicolumn{2}{|c|}{ Keratitis } & \multicolumn{2}{|c|}{ Endophthalmitis } & \multicolumn{2}{|c|}{ Overall } \\
\hline & MRSA & Total SA & MRSA & Total SA & MRSA & Total SA & MRSA & Total SA \\
\hline 2000 & $1(3.7 \%)$ & 27 & $3(12.0 \%)$ & 25 & 0 & 1 & $4(7.6 \%)$ & 53 \\
\hline 2001 & $2(5.3 \%)$ & 38 & $1(3.9 \%)$ & 26 & 0 & 7 & $3(4.2 \%)$ & 71 \\
\hline 2002 & 0 & 32 & $1(4.4 \%)$ & 23 & 0 & 1 & $1(1.8 \%)$ & 56 \\
\hline 2003 & $1(2.9 \%)$ & 34 & 0 & 14 & $1(50.0 \%)$ & 2 & $2(4.0 \%)$ & 50 \\
\hline 2004 & $1(3.0 \%)$ & 33 & $2(10.0 \%)$ & 20 & $1(50.0 \%)$ & 2 & $4(7.3 \%)$ & 55 \\
\hline 2005 & $8(27.6 \%)$ & 29 & $2(10.0 \%)$ & 20 & 0 & 2 & $10(19.6 \%)$ & 51 \\
\hline 2006 & $1(5.6 \%)$ & 18 & $1(6.3 \%)$ & 16 & 0 & 5 & $2(5.1 \%)$ & 39 \\
\hline 2007 & $7(21.2 \%)$ & 33 & $4(9.1 \%)$ & 44 & $1(33.3 \%)$ & 3 & $12(15.0 \%)$ & 80 \\
\hline 2008 & $4(23.5 \%)$ & 17 & $3(11.5 \%)$ & 26 & 0 & 0 & $7(16.3 \%)$ & 43 \\
\hline 2009 & $5(13.2 \%)$ & 38 & $3(12.0 \%)$ & 25 & $3(60.0 \%)$ & 5 & $11(16.2 \%)$ & 68 \\
\hline Total & 30 (10.0\%) & 299 & $20(8.4 \%)$ & 239 & $6(21.4 \%)$ & 28 & $56(9.9 \%)$ & 566 \\
\hline
\end{tabular}




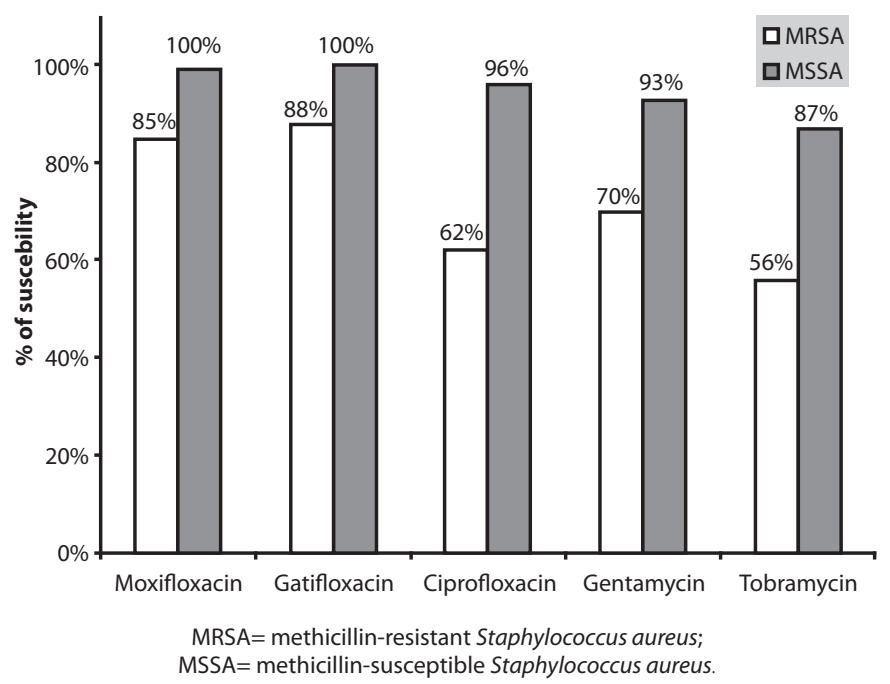

Figure 1. Antibiotic susceptibility rates of methicillin-resistant Staphylococcus aureus and methicillin-susceptible Staphylococcus aureus among all isolates.

isolates, susceptibility rates for the same antibiotics were 86.8, 92.6, $96,99.7$, and $100 \%$, respectively. MRSA isolates were statistically more resistant to all mentioned antibiotics than MSSA isolates ( $p<0.001$ for all comparisons). All isolates were susceptible to vancomycin.

\section{DISCUSSION}

Our study showed the prevalence of MRSA ocular infections over a 10-year period in Brazil. To the best of our knowledge, this is the largest reported case series of ocular infections related to MRSA in South America. These findings must be taken into consideration for effective prevention and treatment strategies.

Previous studies have evaluated the prevalence of MRSA among ocular infections in the United States ${ }^{(8,12-16)}$. In India, Bagga et al. reported a prevalence of MRSA of $43 \%$, which is similar to the prevalence reported in studies from the United States ${ }^{(9)}$. Another recent study performed in China that included 519 ocular infections positive to S. aureus, reported an even higher prevalence of $52.8 \%$ of MRSA ${ }^{(10)}$. However, in Europe Morrissey et al. showed that 22\% of the S. aureus ocular infections were caused by MRSA ${ }^{(17)}$. The $9.9 \%$ prevalence of MRSA reported in our study is considerably lower than the prevalence reported by previous studies in other countries; it is also lower than other studies performed in Brazilian general hospitals ${ }^{(18,19)}$. This may reflect real differences in the prevalence of MRSA, the standards of microbiology tests, or even epidemiological changes over time.

Our results support previous evidences of MRSA lower antibiotic susceptibility rates, compared to MSSA. However, compared with the international literature our susceptibility rates were higher ${ }^{(9,13-17)}$. In our study the susceptibility rates for fourth-generation fluoroquinolones (gatifloxacin and moxifloxacin) were $88 \%$ and $85 \%$, respectively, compared with $18 \%$ and $24 \%$ in the Ocular Tracking Resistance in U.S. Today group (TRUST)(12). Therefore, the use of fourth-generation fluoroquinolones for empiric treatment is still a good option in our region. In contrast, the percentage of MRSA strains susceptible to tobramycin and gentamicin in our study was only $56.4 \%$ and $70 \%$, respectively.

The percentage of MRSA among endophthalmitis cases was found to be significantly higher than the sum of conjunctivitis and keratitis cases (21.4 vs. 9.3\%, respectively, $p=0.036)$. This can be partially explained by the fact that MRSA prevalence might be affected by the previous use of antibiotics ${ }^{(20-23)}$. In our study endophthalmitis cases were frequently associated with surgery, and the prophylactic regimens used in the perioperative period could cause the selection of resistant strains. Further investigations are necessary to confirm and explain this finding.
It is important to highlight that in vitro bacterial susceptibility patterns are not fully equivalent to in vivo susceptibility. Many variables exist in this equation including factors depending on the antimicrobial pharmacokinetics (PK) and pharmacodynamics (PD), microorganism, site of infection, and host. Moreover, it can be difficult to establish breakpoints in susceptibility tests regarding ocular infections. Although the CLSI recommends breakpoints based on PK PD index and microbiological data, those values may not represent the concentrations expected in ocular applications. In addition, it is known that antibiotic concentrations differ according to the form of drug delivery. For example, topical antibiotics are associated with higher concentrations of the drug in the ocular surface and cornea, and intravitreal injection directly increases the amount of drug available in the vitreous. It is also important to remember that different components might change the drug efficacy. Benzalkonium chloride, for instance, is a bacteriostatic and bactericidal agent used as preservative in many marketed formulations including fluoroquinolones. It has been demonstrated that gatifloxacin formulated with benzalkonium chloride has better antimicrobial effect than gatifloxacin alone, with a significant reduction in gatifloxacin minimum inhibitory concentration (MIC) against different ocular pathogens ${ }^{(24)}$.

Direct implication of methicillin resistance on prognosis of ocular infections is still unclear. Although it is obviously influenced by the delay in the introduction of the appropriate antibiotic regimen, virulence factors are also a major concern. Virulence factors are responsible for the capability of the bacteria to cause disease and are correlated with the severity of the disease. Interestingly, the association between increased antibiotic resistance and decreased virulence has already been described for S. aureus ${ }^{(25)}$. Moreover, MRSA showed increased mortality rates compared with MSSA in several studies ${ }^{(26-29)}$. However, little is known about the prognosis associated with MRSA ocular infections. Major et al. evaluated 32 patients with endophthalmitis and reported that the visual acuity after MRSA and MSSA endophthalmitis was similar(14). Since our study had a cross-sectional design, we were unable to make conclusions about prognosis. Future studies should investigate the real implications and management of MRSA in ocular infections.

In conclusion, our study revealed an increasing trend in the overall prevalence of MRSA ocular infections compared to MSSA. Our results also support previous evidence of an association between resistance to methicillin and resistance to non $\beta$-lactam antibiotics, including fluoroquinolones. These findings should be taken in consideration before initiating empiric treatment of ocular infections and illustrates the need for constant bacterial surveillance.

\section{ACKNOWLEGDEMENTS}

We greatly thank Maria Cecilia Yu for the data collection from the electronic database of the ocular microbiology laboratory of the Universidade Federal de São Paulo.

\section{REFERENCES}

1. Solomon R, Donnenfeld ED, Holland EJ, Yoo SH, Daya S, Güell JL, et al. Microbial keratitis trends following refractive surgery: results of the ASCRS infectious keratitis survey and comparisons with prior ASCRS surveys of infectious keratitis following keratorefractive procedures. J Cataract Refract Surg. 2011;37(7):1343-50.

2. Melo GB, Bispo PJ, Yu MC, Pignatari AC, Höfling-Lima AL. Microbial profile and antibiotic susceptibility of culture-positive bacterial endophthalmitis. Eye (Lond). 2011;25(3):382-7; quiz 388. Comment in Eye (Lond). 2011;25(10):1379.

3. Pandian DG, Babu RK, Chaitra A, Anjali A, Rao VA, Srinivasan R. Nine years' review on preseptal and orbital cellulitis and emergence of community-acquired methicillinresistant Staphylococus aureus in a tertiary hospital in India. Indian J Ophthalmol. 2011;59(6):431-5.

4. Asbell PA, Sahm DF, Shaw M, Draghi DC, Brown NP. Increasing prevalence of methicillin resistance in serious ocular infections caused by Staphylococcus aureus in the United States: 2000 to 2005. J Cataract Refract Surg. 2008;34(5):814-8.

5. Plata K, Rosato AE, Wegrzyn G. Staphylococcus aureus as an infectious agent: overview of biochemistry and molecular genetics of its pathogenicity. Acta Biochim Pol. 2009;56(4):597-612. 
6. Hiramatsu K, Hanaki H, Ino T, Yabuta K, Oguri T, Tenover FC. Methicillin-resistant Staphylococcus aureus clinical strain with reduced vancomycin susceptibility. J Antimicrob Chemother. 1997;40(1):135-6. Comment in J Antimicrob Chemother. 1998; 41(2):311-3.

7. Zilberberg MD, Shorr AF, Kollef MH. Growth and geographic variation in hospitalizations with resistant infections, United States, 2000-2005. Emerg Infect Dis. 2008 14(11):1756-8.

8. Haas W, Pillar CM, Torres M, Morris TW, Sahm DF. Monitoring antibiotic resistance in ocular microorganisms: results from the Antibiotic Resistance Monitoring in Ocular microrganisms (ARMOR) 2009 surveillance study. Am J Ophthalmol. 2011;152(4): 567-74. e3.

9. Bagga B, Reddy AK, Garg P. Decreased susceptibility to quinolones in methicillinresistant Staphylococcus aureus isolated from ocular infections at a tertiary eye care centre. Br J Ophthalmol. 2010;94(10):1407-8.

10. Hsiao CH, Chuang CC, Tan HY, Ma DH, Lin KK, Chang CJ, et al. Methicillin-resistant Staphylococcus aureus ocular infection: a 10-year hospital-based study. Ophthalmology. 2012;119(3):522-7. Comment in Ophthalmology. 2013;120(1):218-9. Ophthalmology. 2012;119(8):1719-1719.e1; author reply 1720.

11. Clinical and Laboratory Standards Institute. Performance Standards for Antimicrobial Susceptibility Testing. Wayne, PA: CLSI; c2012.

12. Asbell PA, Colby KA, Deng S, McDonnell P, Meisler DM, Raizman MB, et al. Ocular TRUST: nationwide antimicrobial susceptibility patterns in ocular isolates. Am J Ophthalmol. 2008;145(6):951-8.

13. Elsahn AF, Yildiz EH, Jungkind DL, Abdalla YF, Erdurmus $M$, Cremona FA, et al. In vitro susceptibility patterns of methicillin-resistant Staphylococcus aureus and coagulasenegative Staphylococcus corneal isolates to antibiotics. Cornea. 2010;29(10):1131-5. Erratum in Cornea. 2010;29(12):1470.

14. Major JC Jr, Engelbert M, Flynn HW Jr, Miller D, Smiddy WE, Davis JL. Staphylococcus aureus endophthalmitis: antibiotic susceptibilities, methicillin resistance, and clinical outcomes. Am J Ophthalmol. 2010;149(2):278-83.e1.

15. Freidlin J, Acharya N, Lietman TM, Cevallos V, Whitcher JP, Margolis TP. Spectrum of eye disease caused by methicillin-resistant Staphylococcus aureus. Am J Ophthalmol. 2007; 144(2):313-5.

16. Walvick MD, Amato M. Ophthalmic methicillin-resistant Staphylococcus aureus infections: sensitivity and resistance profiles of 234 isolates. J Community Health. 2011 36(6):1024-6.

17. Morrissey I, Burnett R, Viljoen L, Robbins M. Surveillance of the susceptibility of ocula bacterial pathogens to the fluoroquinolone gatifloxacin and other antimicrobials in Europe during 2001/2002. J Infect. 2004;49(2):109-14.
18. Brites C, Silva N, Sampaio-Sá M. Temporal evolution of the prevalence of methicillinresistant Staphylococcus aureus in a tertiary hospital in Bahia, Brazil: a nine-year evaluation study. Braz J Infect Dis. 2006;10(4):235-8.

19. Gales AC, Sader HS, Ribeiro J, Zoccoli C, Barth A, Pignatari AC. Antimicrobial susceptibility of gram-positive bacteria isolated in Brazilian hospitals participating in the SENTRY Program (2005-2008). Braz J Infect Dis. 2009;13(2):90-8.

20. Tacconelli E, De Angelis G, Cataldo MA, Pozzi E, Cauda R. Does antibiotic exposure increase the risk of methicillin-resistant Staphylococcus aureus (MRSA) isolation? A systematic review and meta-analysis. J Antimicrob Chemother. 2008;61(1):26-38.

21. Fintelmann RE, Hoskins EN, Lietman TM, Keenan JD, Gaynor BD, Cevallos V, et al, Topical fluoroquinolone use as a risk factor for in vitro fluoroquinolone resistance in ocular cultures. Arch Ophthalmol. 2011;129(4):399-402.

22. Milder E, Vander J, Shah C, Garg S. Changes in antibiotic resistance patterns of conjunctival flora due to repeated use of topical antibiotics after intravitreal injection. Ophthalmology. 2012;119(7):1420-4.

23. Otsuka T, Yoshida K, Komiyama K, Ishikawa Y, Zaraket H, Okazaki M. Prevalence of methicillin-resistant Staphylococcus aureus among children in a region with controlled antimicrobial use. Jpn J Infect Dis. 2011;64(5):436-8.

24. McDonald M, Blondeau JM. Emerging antibiotic resistance in ocular infections and the role of fluoroquinolones. J Cataract Refract Surg. 2010;36(9):1588-98. Review.

25. Rudkin JK, Edwards AM, Bowden MG, Brown EL, Pozzi C, Waters EM, et al. Methicillin resistance reduces the virulence of healthcare-associated methicillin-resistant Staphylococcus aureus by interfering with the agr quorum sensing system. J Infect Dis. 2012;205(5):798-806.

26. Hanberger $\mathrm{H}$, Walther S, Leone M, Barie PS, Rello J, Lipman J, Marshall JC, Anzueto A, Sakr Y, Pickkers P, Felleiter P, Engoren M, Vincent JL; EPIC II Group of Investigators. Increased mortality associated with methicillin-resistant Staphylococcus aureus (MRSA) infection in the intensive care unit: results from the EPIC II study. Int J Antimicrob Agents. 2011:38(4):331-5. Comment in Future Microbiol. 2012;7(2):189-91.

27. Cosgrove SE, Sakoulas G, Perencevich EN, Schwaber MJ, Karchmer AW, Carmeli Y. Comparison of mortality associated with methicillin-resistant and methicillin-susceptible Staphylococcus aureus bacteremia: a meta-analysis. Clin Infect Dis. 2003;36(1):53-9. Comment in Clin Infect Dis. 2003; 37(3):459; author reply 459-60. Clin Infect Dis. 2003;37(6):866-8; author reply 868-9.

28. Engemann JJ, Carmeli Y, Cosgrove SE, FowlerVG, Bronstein MZ, Trivette SL, et al. Adverse clinical and economic outcomes attributable to methicillin resistance among patients with Staphylococcus aureus surgical site infection. Clin Infect Dis. 2003;36(5):592-8.

29. Pardo L, Vola M, Macedo-Viñas M, Machado V, Cuello D, Mollerach M, et al. Community-associated methicillin-resistant Staphylococcus aureus in children treated in Uruguay. J Infect Dev Ctries. 2013;7(1):10-6.

\section{Arquivos Brasileiros de Oftalmologia}

Nos artigos enviados para publicação, os nomes dos autores e suas afiliações devem estar completos.

Isso facilitará a indexação e os links com as bases de dados e o CV Lattes.

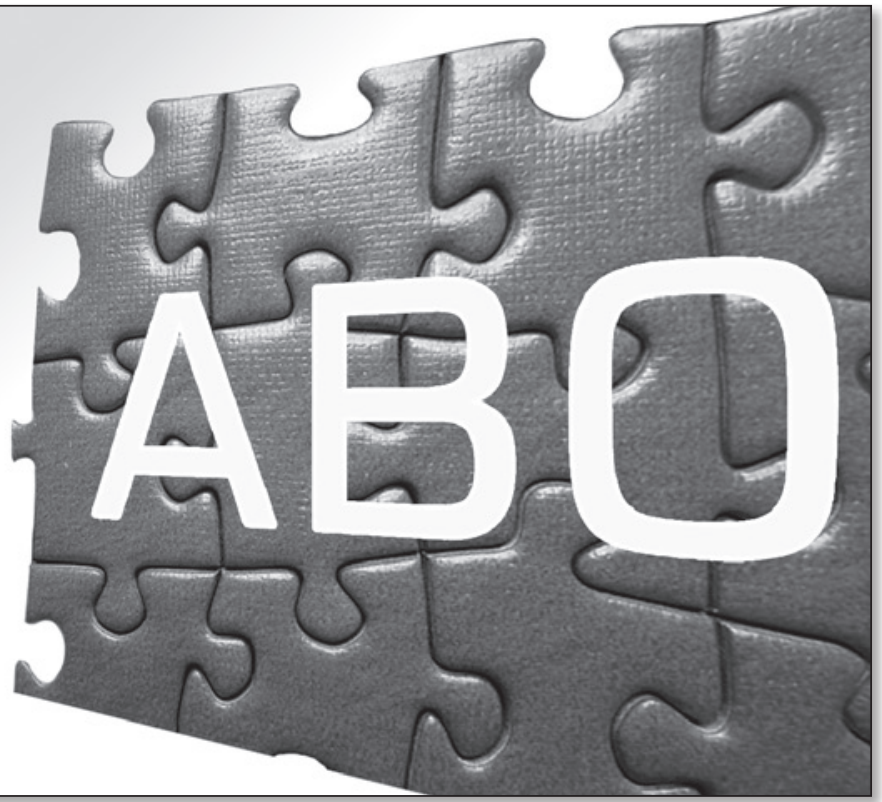

